\title{
A new species of copepod (Siphonostomatoida: Caligidae) parasitic on the striped trumpeter, Latris lineata (Forster), from Tasmania
}

\author{
MELANIE ANDREWS ${ }^{1,2}$, NATHAN BOTT $^{3,4}$, STEPHEN BATTAGLENE $^{1} \&$ BARBARA NOWAK $^{2}$ \\ ${ }^{\prime}$ Tasmanian Aquaculture and Fisheries Institute and Aquafin Cooperative Research Centre, University of Tasmania, Marine Research \\ Laboratories, Nubeena Crescent, Taroona, Tasmania 7053, Australia. \\ E-mails: andrewsm@utas.edu.au; Stephen.Battaglene@utas.edu.au \\ ${ }^{2}$ Tasmanian Aquaculture and Fisheries Institute, National Centre for Marine Conservation and Resource Sustainability, AMC and \\ Aquafin CRC, University of Tasmania, Launceston, Tasmania 7250, Australia.E-mail: b.nowak@utas.edu.au \\ ${ }^{3}$ South Australian Research and Development Institute, GPO Box 397, Adelaide, SA 5001, Australia. E-mail: nbott@unimelb.edu.au \\ ${ }^{4}$ Department of Veterinary Science, University of Melbourne, 250 Princes Hwy, Werribee, Victoria 3030, Australia.
}

\begin{abstract}
A new species of caligid copepod (Siphonostomatoida), Caligus nuenonnae n. sp., is described based on material collected from the body surface of striped trumpeter [Latris lineata (Forster)] reared at the Tasmanian Aquaculture and Fisheries Institute, Marine Research Laboratories, Australia. Caligus nuenonnae n. sp. is characterised by the following combination of features: 1) female genital complex with a mid-lateral indentation and highly concave posterior margin; 2) 1-segmented abdomen in the female that is about one-third the length of the genital complex; 3 ) distinctly broader first abdominal somite relative to the second abdominal somite in the male; 4) antenna with a spatulate process on the proximal segment; 5) recurved postantennal process without a basal accessory process; 6) female maxilliped with a proximal ridged protrusion on the corpus; 7) sternal furca with widely separated, apically truncate tines; 8) distal exopodal segment of leg 1 with a lateral flange on each apical spine and an accessory process on apical spines two and three; 9) leg 3 protopod with two adhesion pads on the dorsolateral surface; 10) leg 4 exopod 2-segmented, with I-0; I, III armature; 11) terminal exopodal segment of leg 4 with the outer apical spine being slightly shorter than the middle apical spine; 12) male maxillulary dentiform process with numerous small points embossed on the surface; and 13) male legs 5 and 6 represented by distinct lobate projections.
\end{abstract}

Key words: Caligus, parasitic copepods, marine fish, Australia

\section{Introduction}

Striped trumpeter, Latris lineata (Forster), has recently been identified as a future aquaculture species in Australia, with progress being made in the areas of broodstock and hatchery management, egg incubation and larval rearing at the Tasmanian Aquaculture and Fisheries Institute (TAFI), Marine Research Laboratories, Hobart, Australia (Morehead \& Hart 2003; Bransden et al. 2005; Battaglene et al. 2006; Battaglene \& Cobcroft 2007). Nevertheless, knowledge of the parasites and diseases affecting this fish in captivity is relatively limited (Grossel et al. 2005). Two parasite species, namely the myxozoan Kudoa neurophila (Grossel, Dyková, Handlinger \& Munday, 2003) and the copepod Chondracanthus goldsmidi Tang, Andrews \& Cobcroft, 2007, have been reported thus far from cultured striped trumpeter. Both parasites have been associated with host mortality: $K$. neurophila infects the host's central nervous system, which disrupts the host's swimming and feeding behaviour; the presence of large numbers of $C$. goldsmidi on the gills and inner opercula of striped trumpeter juveniles has been linked to host mortality (Grossel et al. 2003; Grossel 2005; Tang et al. 